\title{
Kattlım Perspektifiyle Kadın Muhtarların Meslek ve Rol Algılarına iliş̧kin Keşifsel Bir Çalışma
}

\section{An Explorative Study Regarding Women Muhtars' Profession and Role Perceptions}

Duru Şahyar Akdemir ${ }^{1}$, Aytül Ayşe Cengiz² ${ }^{\circ}$

\section{Öz}

Günümüzde katlım, mahalle düzeyinden başlayarak ulusal düzeye uzanan bir mekanizma içinde seçilen temsilciler aracılığıyla gerçekleşmektedir. Katılımın ilk basamağını mahalle oluşturmaktadır. Mahalle düzeyindeki temsilci ise muhtardır. Bu bağlamdan hareketle çalışmada Eskişehir'de görev yapan kadın muhtarların mesleklerine ilişkin algıları, liderlik ve katılım konularındaki tutum ve davranışları nitel paradigmanın esasları doğrultusunda araştırılmıştır. 11 (onbir) kadın muhtarla yapılan görüşmeler neticesinde elde edilen verilere sistematik ve betimsel analiz yapılmıştır. Bulgulara göre muhtarların kadın olmaya atfedilen toplumsal cinsiyet özellikleri üzerinden muhtarlık mesleğini tanımladıkları, görev bilinçlerinin yüksek olduğu, muhtarlığı seçmelerinde ve devam ettirmelerinde -eş- desteğini önemli gördükleri saptanmıştr. Ayrıca mahalle sakinleriyle kurdukları ilişkiler ve sorunları çözüm yöntemleri katılımcı liderlikten ziyade paternalistik liderlik özelliklerini taşımaktadır. Son olarak muhtarların kent yönetimine yeterli katıım olanağı bulamadıkları ortaya çıkmıştr. Çalışmanın bulguları doğrultusunda kuramsal ve pratik öneriler geliştirilmiştir.

\section{Anahtar Kelimeler}

Kamu yönetimi, Kadın muhtarlar, Katılım, Liderlik, Paternalizm

\begin{abstract}
Today, participation takes place through several direct participation tools and is also facilitated by representatives elected at the neighborhood as well as national levels. Involvement in neighborhood activities is the first step toward social participation; as representatives of citizens at the neighborhood
\end{abstract}

1 Sorumlu Yazar: Duru Şahyar Akdemir (Dr. Öğr. Üyesi), Anadolu Üniversitesi, Açıköğretim Fakültesi, Kamu Yönetimi ve Siyaset Bilimi, Eskişehir, Türkiye. E-posta: dsakdemir@anadolu.edu.tr ORCID: 0000-0003-2374-9770

2 Aytül Ayşe Cengiz (Doç. Dr.), Anadolu Üniversitesi, İktisadi ve İdari Bilimler Fakültesi, Çalışma Ekonomisi ve Endüstri İlişkileri, Eskişehir, Türkiye. E-posta: aacengiz@anadolu.edu.tr ORCID: 0000-0002-7090-289X

Atıf: Sahyar Akdemir, D. ve Cengiz, A. A. (2021). Katılım Perspektifiyle Kadın Muhtarların Meslek ve Rol Algılarına İlişkin Keşifsel Bir Çalışma. Journal of Social Policy Conferences, 81, 421-449. https://doi.org/10.26650/jspc.2021.81.871612 
level, muhtars participate actively in the local decision-making process. This study adopts the principles of the qualitative paradigm to investigate how women muhtars working in Eskişehir perceive their professions, attitudes and roles pertaining to their leadership positions and participation in various activities. Systematic and descriptive analyses were performed on the data obtained from interviews of 11 women muhtars. The findings revealed that muhtars primarily perceive their profession in terms of the gender attributes ascribed to the role. Women muhtars possess high levels of consciousness and believe that support from a woman's husband plays a pivotal role in helping her select and then progress in the muhtar profession. In addition, the relationships that they establish with residents and the problem-solving and decision-making strategies they adopt reflect the characteristics of paternalistic-as opposed to participatoryleadership. Finally, the muhtars believed that they did not have sufficient decision-making powers in the city's administrative process. Theoretical and practical suggestions were developed in line with the findings of the study.

\section{Keywords}

Public management, Women muhtars, Participation, Leadership, Paternalism 


\section{Extended Summary}

A muhtar's role is an institution based on the principle of participation. Thus, muhtars are expected to collaborate with formal and informal stakeholders engaged in cooperation and coordination and participate in the decision-making process. In this context, the basic assumptions of this study are as follows: The muhtars' active participation in the local decision-making processes and their adoption of participative decision-making strategies at the neighborhood level ensure their adherence to the philosophy of the muhtar's institution. Consequently, women with effective decision-making skills are more likely to be perceived as potential leaders.

In this study, an exploratory research was conducted on 11 women muhtars from 30 women in the Eskişehir province by means of the interview technique, a qualitative research method. Female muhtars were selected for this study because the gender norms and ideologies in Turkey are characterized by inadequate representation of women in the public arena (Rudman, 2012). Women leaders are perceived as less qualified compared to men and are typically not chosen as leasers by the society (Aycan, 2006). The role of the muhtars as leaders involves constant interactions with neighborhood residents, municipalities, and city councils, together with active participation in the neighborhood activities. In this context, the attitudes and perceptions of women muhtars with regard to their professional roles and leadership perspectives have been explored.

Owing to the pandemic, the interviews for this study were held online in May and June 2020. Five themes were obtained from the content of the data analyzed: mother-bond leader, spouse and family support, participant leader, insufficient leader participation, and ineffective authority. The first theme that emerged among the participants was that female muhtars think that the profession of a muhtar or the "head of the locality" is compatible with the characteristics socially attributed to women. The participants stated that the role of a muhtar requires discipline, perseverance, communication skills, a smiling countenance, the ability to talk pleasantly, patience, and sincerity; they add that because women possess such characteristics, they are well-suited to this profession. Women's perception of this profession in terms of motherhood has also caused a shift in their duties and responsibilities. This situation has resulted in the prevalence of the paternalistic leadership style in ostensibly 
female-dominated roles in Turkey. The second theme is that spousal and family support is the main source of support for women muhtars when they opt for this profession. The third theme is that women muhtars are not professionally qualified to participate in leadership roles and professions. It has been concluded that the profession entails an informal interaction process conducted in an environment characterized by face-to-face interactions with various individuals and entities as opposed to systematic and professional interactions with the neighborhood residents. Such interactions help muhtars prioritize their activities and find solutions to the existing problems. Another theme that can be considered both a determinant as well as an outcome of this result is that female muhtars cannot participate. Some of the participants stated that a neighborhood assembly takes place in the locality. However, some others suggested that they held such local assemblies even though they these were not a mandate for the muhtar women in the locality. In this case, it was concluded that the participants did not have sufficient information about the establishment and functions of neighborhood assemblies or the participatory processes involved therein. The last theme suggests that women muhtars who are unable to participate in their neighborhood activities believe that they are not represented in the official decision-making processes and that their authority is limited.

These research results demonstrate that participation is a learned norm; participation-based management as an educational philosophy and culture should take place at the micro, meso and macro levels of the society. Norms and values such as participation, democracy, reconciliation, and multi-directional feedback, all of which are a part of the profession's principles, cannot translate to practical implementation even if individuals adopt these values theoretically. The qualifications of the muhtar profession should be established, and training should be provided to muhtar candidates and muhtars in subjects such as governance, participation, and local democracy, according to the criteria established within the framework of professional competencies. The "Mother-bond" leadership style causes women muhtars - who typically establish an emotional bond with the neighborhood - to overlook their professional leadership roles.

The next phase of this research would entail a study comparing the roles of female and male muhtars. In this way, it will be possible to compare the responsibilities, participatory leadership attitudes, and behaviors of female and male muhtars. 


\section{Katılım Perspektifiyle Kadın Muhtarların Meslek ve Rol Algılarına İlişkin Keşifsel Bir Çalışma}

Muhtarlık kurumunun tarihi 1800'lerin başına dek uzanmaktadır. Muhtarlık kurumu, kentlerde düzenin ve güvenliğin sağlanması amacıyla ilk kez 1829'da İstanbul'da kurulmuştur. Birçok kere hukuki mevzuatla yapısı, görevi, işlevi düzenlenmiş olan kurumun bugün ülkemizde 50.157 tane temsilcisi bulunmaktadır. Muhtarlar önceleri sınırlı sorumluluklara sahip olup, kısıtlı yetkilerle iş görürlerken bugün, -5393 sayılı Belediye Kanunu'nda da belirtildiği üzere- kent yönetiminin bir paydaşı olarak konumlandırılmaktadır.

5393 sayılı Belediye Kanunu'nun 9. maddesinde muhtarın görevleri "mahalle sakinlerinin gönüllü katılımıyla ortak ihtiyaçları belirlemek", "mahallenin yaşam kalitesini geliştirmek", "belediye ve diğer kamu kurum ve kuruluşlarıyla ilişkilerini yürütmek", "mahalle ile ilgili konularda görüş bildirmek" ve "diğer kurum ve kuruluşlarla işbirliği yapmak” olarak sıralanmaktadır. Diğer taraftan mahalle muhtarlarının kendi mahallelerinin temsilcileri olarak yerel kararların alınmasında söz sahibi olduğu bilinmektedir. Zira muhtarlar, kent konseylerine ve kente dair konuların görüşüldüğü ihtisas komisyonlarına katılım sağlayarak görüş bildirebilmektedirler. Görev tanımlarıyla birlikte düşünüldügünde bu örnekler bize, muhtarlık kurumunun kent yönetiminde söz sahibi bir mekanizma olduğunu ve kurumun kentle ilgili kararların alınmasında sorumluluk sahibi olduğunu göstermektedir. 5393 sayılı Kanun ile belirtilen görevler muhtarlara birtakım sorumluluklar yüklemektedir. Bu sorumluluklardan bir tanesi de muhtarların katılımcı bir yaklaşımla mahallelerini temsil etmeleridir. Ancak diğer taraftan bireylerin sınırlı karar alıcılar oldukları varsayımının da göz önünde tutulması gerekmektedir. Buna göre karar alma sürecinin bu sınırlılığın farklı birey ve kurumlarla bir araya gelerek, görüş ve fikirleri paylaşarak, konu ve sorunlara yönelik kaliteli etkileşim kurarak yönetilmesi gerekmektedir. Çünkü katılımcı süreçler geliştirilerek alınan kararlar ihtiyaçların ve hak temelli, sürdürülebilir politikaların belirlenmesine olanak sağlar. Ayrıca karar alma süreçlerine katılım sağlayan kişilerin yaşam alanlarına olan aidiyetleri kuvvetlenir. Bu doğrultuda muhtarların mahalle düzeyinde karar alırken mahalle sakinleri, mahalle meclisi, mahallede hareketlilik gösteren sivil toplum kuruluşları gibi aktörlerin görüşlerine başvurması ve kararları, belediye ya da valiliğe iletilecek talepleri katılımcı süreçler içinde belirlemesi gerekmektedir. $\mathrm{Bu}$ çerçevede çalışmanın temel varsayımları şöyledir: Muhtarlar, yerel düzeyde 
karar alma süreçlerine etkin katılım sağladıklarında ve mahalle düzeyinde kararları katılımcı yöntemlerle aldıklarında hem 5393 sayılı Kanun'la kendilerine atfedilen görevlere uygun hareket etmiş olurlar, hem de muhtarların etkin karar verme becerileri sayesinde lider olarak algılanma potansiyelleri artar.

Çalışmanın amacı Eskişehir'de kadın muhtarların mesleki rollerini, katılımcı liderlik anlayışlarını onların dünyasından anlamaya çalışmaktır. Bu sayede yerel demokrasinin gerçekleşmesinde kadınların eksik temsil sorununu çözmeye dolaylı da olsa destek sağlanabilecektir. İlgili alan yazınında muhtarlık kurumunun tarihçesi, gelişimi, şimdiki durumu, muhtarlık kurumuna yönelik algılamalar konularında önemli çalışmalar bulunmaktadır (Bkz: Alada, 2008; Akman, 2018; Arıkboğa, 1999; Bulut, 2001; Çadırcı, 1993; Kavruk, 2018). Ancak ilgili alan yazınında kadın muhtarlara yönelik ve kadın muhtarların mesleki algıları, katılım, katılımcı liderlik tutum ve davranışları hakkında hazırlanmış sınırlı çalışma olduğu düşünülmektedir. Bu bağlamda ele edilen sonuçların kadın liderliğin kamusal alandaki varlığını değerlendirmek açısından ilgili alanlara katk1 vereceği düşünülmektedir.

Bu kapsamda çalışmada ilk olarak mahalle yönetimi ve katılım konusundan söz edilecektir. İkinci olarak katılımcı liderlik konusu kadın ve muhtar çerçevesinden ele alınacaktır. Çalışmanın bir sonraki bölümü saha araştırması ve bulgulardan oluşmaktadır. Son bölümde ise saha araştırması ile erişilen bulgular dikkate alınarak değerlendirme yapılacak ve öneriler sunulacaktır.

\section{Katılım ve Mahalle Yönetimi}

Katılım kavramının tanımı ve kapsamı konusunda bir fikir birliği bulunmamaktadır. İlgili yazında kavram, "katılım” şeklinde ifade edilebildiği gibi "katılma" olarak da kullanılmaktadır. Kavramın kullanımındaki bu belirsizlik kavramı niteleyen sıfatlarla durumu daha karmaşık hale getirmektedir. Yazında yer alan çalışmalarda, yazarlar "siyasal katılma", "yönetsel katılma", "devlet yönetimine katılma", "siyasal katılım” ve "yönetsel katılım” gibi ayrımlar yapmakta veya kavramı dar ve geniş anlamlarıyla ele alma yolunu seçmektedirler. Örneğin Eroğul (1998, s. 18), devlet bulunmayan yerde siyasetin olmadığını ancak siyasetin bulunduğu yerde mutlaka devletin bulunduğunu belirterek siyasal katılmayı "devlet yönetimine katılma” olarak ele almıştır. Çam (2011, s. 169) ise siyasal katılmayı dar anlamda "siyasal sistem içinde 
yurttaşların doğrudan ya da dolaylı biçimde yöneticilerin seçimini ve kararlarını etkilemeyi amaçlayan eylemlerin bütünü” olarak tanımlamıştır. Çukurçayır (2012, s. 39), kavramın dar anlamda sadece "seçimlere katılma" olarak tanımlanabilirken geniş anlamda ise "bürokrasi ve siyasal karar alma sürecinin her aşamasına katılma" olarak ele alınabileceğini belirtmektedir. Eryılmaz (2016, s. 61-62) ise katılım kavramını "siyasal katılım" ve "yönetsel katılım" olarak ikiye ayırmaktadır. Buna göre "siyasal katılım, bireylerin ve grupların ulusal ve yerel düzeyde siyasal yöneticilerini seçmek ve yöneticileri kendi istek ve çıkarları doğrultusunda karar almalarını sağlamaya yönelik gösterdikleri her türlü davranış ve eylem" olarak tanımlanmaktadır. Yönetsel katılım ise "seçim ve seçime ilişkin faaliyetler dişında, kamu hizmetleriyle ilgili temel kararların hazırlanması, olgunlaştırılması, karara dönüştürülmesi ve bu kararların uygulanması aşamalarından birine, birkaçına veya tamamına, o karardan doğrudan ya da dolaylı olarak etkilenecek olanların katkıda bulunması" olarak tanımlanmaktadır. Bu çalışmada belirtilen ayrımlar kapsam dışı bırakılarak katılım kavramı, basit ve genel bir şekilde "yönetilenlerin karar alma süreçlerine katılım göstermeleri” olarak ele alınmıştır.

Bu çerçevede mahalle düzeyinde katılım denildiğinde mahalle sakinlerinin mahallede alınan kararlara katılım göstermeleri anlaşılmaktadır. Mahalle kelimesi Türk Dili Kurumu'nun sözlügünde “bir şehrin, bir kasabanın, büyükçe bir köyün bölündüğü parçalardan her biri” ve "bu parçalarda oturan insanların tamamı” olarak tanımlanmaktadır (TDK Sözlük). Kelimenin "konaklanan yer” anlamına gelen Arapça “mahal” kelimesinden türediği belirtilmektedir (Kavruk, 2018, s. 13).

5393 sayılı Belediye Kanunu'na göre ise mahalle "belediye sınırları içinde, ihtiyaç ve öncelikleri benzer özellikler gösteren ve sakinleri arasında komşuluk ilişkisi bulunan idari birim" olarak tanımlanmaktadır (5393 sayılı Kanun, 2005, 3. madde). Ülkemizde mahalle kurumunun temelleri Osmanlı dönemine dek uzanmaktadır. İlk kez 1829 yılında İstanbul'da kurulmuş olan muhtarlık kurumu sonrasında taşraya yayılmıştır. Kurumun ortaya çıkmasına neden olan iki önemli gelişme bulunduğu ifade edilmektedir. Bunların ilki, 1826 yılında "Yeniçeri Ocağı'nın kaldırılması”, ikincisi ise "nüfus değişiklikleri”dir. Yeniçeri Ocağı'nın kaldırılması "asayiş ve güvenlik" sorunlarına; "taşradan gelen nüfusun" sayısındaki artış da "işsizlik ve düzensizlik" sorunlarına yol açmıştır (Eryılmaz, 2017, s. 222). Bu sorunları bertaraf etmek için ortaya çıkan kurum ise "muhtarlık 
kurumu" olmuştur. Bu nedenle birçok kaynakta mahalle "milli ve yerli bir kamu yönetimi birimi” olarak tanımlanmaktadır (Özservet Çakırer, 2019, s. 8).

Her ne kadar, kamu yönetimi birimleri içinde konumlandırılsa da mahallenin yerel yönetim birimleri içindeki yeri oldukça farklıdır. Bunun ilk nedeni mahallenin tüzel kişiliğinin bulunmamasıdır. İkinci nedeni ise mahalle yönetiminin işlerini "hizmet ve sorumluluk bakımından" hem belediyeye hem de mülki idareye bağlı olarak yürütmesidir. Muhtar ve ihtiyar heyetinden oluşan mahalle yönetimi seçilerek göreve geldiği için bu yönetim bir yandan yerel yönetim birimlerine benzetilirken, diğer bir yandan da "mülki makamların, mahalle muhtarları üzerinde hiyerarşik denetimi artıran yetkilerinin” bulunması da kuruma kamusal bir nitelik kazandırmaktadır (Eryılmaz, 2016, s. 221-222). 5393 sayılı Kanun'da yer alan “belediye sınırları içinde mahalle kurulması, kaldırılması, birleştirilmesi, bölünmesi, adlarıyla sınırlarının tespiti ve değiştirilmesi, belediye meclisinin kararı ve kaymakamın görüşü üzerine valinin onayı ile olur" ifadesi de bu ikili durumu yansitmaktadır (5393 sayılı Kanun, 2005 , 9. madde). Aynı Kanun, belediyelerin, mahalleye ve muhtarlığa ihtiyaçlar çerçevesinde yardım ve destek sağlayacağını belirtmiştir. Yine belediyelerin, mahallelerin ortak isteklerini ve ihtiyaçlarını da dikkate alarak kararlarını alması gerektiği de Kanun'da ifade edilmiş bir diğer önemli konudur. Bu durumda arac1lık rolü üstlenen muhtarlık kurumu, mahallenin ortak istek ve ihtiyaçlarını belediyeye iletecek ve mahalle ile belediye arasındaki ilişkiyi kuracak bir mekanizma olarak karşımıza çıkmaktadır. Zira "Muhtarlar Günü” konulu Genelge'de de "yerel demokrasinin en eski örneğini temsil ettiği”" ifade edilen muhtarlık kurumunun "çağdaş kamu yönetimi anlayışının en temel gereksinimlerinden biri olan katılımcılığın sağlanmasında önemli bir görev" sahibi olduğu dile getirilmiştir (29507 sayılı Genelge, 19.10.2015). Genelge'de ayrıca muhtarlık kurumunun "köy ve mahalle sakinleri” ile "devlet kurumları" arasında aracılık ettiği belirtilmiştir. Mahalle yönetiminin bir organı olarak muhtarın görevleri, 5393 sayılı Kanun'da belirtilmiştir (5393 sayılı Kanun, 2005, 9.madde). Muhtarların kurullara üyelik görevleri, seçim dönemlerindeki görevleri, cadde ve sokaklarla ilgili görevleri ve kamu sağlığı ile ilgili görevleri de bulunmaktadır (Bulut ve Akın, 2019, s. 51-52). Bu çerçevede muhtarlar, mahalle düzeyinde "sandık seçim kurulu", "sağlık merkez kurulu” ve "arsa bedel tespit komisyonu" gibi kurul ve komisyonlar içinde yer almaktadırlar (Bulut ve Akın, 2019, s. 51). Bunların dışında herhangi bir salgın durumunda muhtarlar "şüphelileri bildirmek", "ihtiyacı olanları tespit etmek" ve "afet 
zamanında yardım alacakları belirlemek" gibi görevleri yerine getirmektelerdir. Bulut ve Akın (2019, s. 52) tarafindan bu görevlerin muhtarları "inşa edici" bir konuma taşıdığı belirtilmiştir. Ayrıca muhtarların kentte oluşturulacak ihtisas komisyonlarına katılmaları ve kent konseylerinde temsil edilmeleri de Belediye Kanunu ile güvence altına alınmıştır (5393 sayılı Kanun 2005, 24. ve 76. maddeler; Kavruk, 2018, s. 134).

Bu çerçevede muhtarların sadece kâğıt işleriyle uğraşan kişiler olmadıkları, temsil ettikleri kurumun varoluş felsefesine uygun olarak önemli görevler üstlendikleri ifade edilmelidir. Bu konuda Gül (2019, s. 36-39), "yasalarca verilen bazı görevleri mahallede takip eden seçilmiş kamu görevlisi” olarak tanımladığ 1 muhtarın idari görevlerinin yanında muhtarlık kurumuna toplumda atfedilen roller sonucunda "mahallenin önde gelen kişisi”" ve "devlet nezdinde mahallenin temsilcisi” olarak algılandığını belirtmiştir. Kavruk (2018, s.176) da muhtarın "mahalleli gözünde" kendileri tarafından seçilmiş olduğu için "temsilci” olarak görüldüğünden söz etmiştir. Ayrıca muhtarın "mahalleli ile yakın ilişkiler kuran, mahallenin ihtiyaçlarını yerinde tespit eden, mahallenin asayişini takip ve teminde önemli rol üstlenen ve gerektiği durumlarda da halka liderlik eden kişiler” olduğu da belirtilmiştir (Gül, 2019, s. 35). Öktem (2019, s. 70) de muhtarı "mahallede aklıselim bir kamu görevlisi" olarak tanımlamakta ve yerel yönetim birimi olarak muhtarlık kurumunun "sokak düzeyinde bürokrat” kavramını çağrıştırdığını ifade etmiştir.

Ülkemizdeki muhtar sayısı 50.157'dir. Kadın muhtarların sayısı ise 1071'dir. Bu doğrultuda kadın muhtarların sayısı genel sayının \% 2,14'üne karşılık gelmektedir. 2014-2019 döneminde ise bu oranın \%1,3 olduğu ifade edilmiştir (URL 1). Her ne kadar bir önceki dönemle kıyaslandığında kadın muhtar sayısı yaklaşık \% 45 oranında artış göstermişse de genel karşılaştırmaya bakıldığında kadın muhtarların sayısının erkek muhtar sayısına oranla oldukça düşük olduğu görülmektedir. İl bazında bakıldığında en fazla kadın muhtarın bulunduğu iller sırasıyla İstanbul, Ankara, İzmir, Bursa, Balıkesir, Eskişehir, Kocaeli, Manisa, Mersin, Antalya olarak sıralanmaktadır. Bitlis ve Sinop gibi bazı illerde ise kadın muhtar bulunmadığı belirtilmiştir (URL 1). Bu göstergeler akıllara Eroğul'un (1998, s. 110) "kadınlar politikanın kıyısında yaşamakta, yasaların tanıdığı formel siyasal hak eşitliğinden fiilen yararlanamamaktadır” ifadesini getirmektedir. 


\section{Kadın: Muhtar ve Katılıme Lider Olmak}

Cinsiyete dayalı işbölümünün devamı olan ve tanımlayan/kural koyan hegemonik düzenin inşa ettiği kadınlık kodları her alanda olduğu gibi kamu yönetiminin en önemli temsil araçlarından biri olan muhtarlıkta da kendini göstermektedir. Birleşmiş Milletler 2020 yılında ilk kez Toplumsal Cinsiyet Sosyal Norm Endeksi yayımlamıştır. Raporda ölçülen boyutlardan biri siyasi boyuttur ve şu göstergelerle ölçülmektedir: "Erkekler kadınlardan daha başarılı siyasi liderdir." ve "Kadınlar da erkekler gibi aynı haklara sahiptir." Türkiye bu iki gösterge bazında güçlü bir siyasal yanlılığa sahiptir. Erkeklerin daha başarılı olduğunu düşünen kadın ve erkeklerin oranı \% 76,2' dir. Benzer şekilde Dünya Değerler Araştırması'nın (2012) Türkiye verilerine göre “Erkekler kadınlardan daha iyi yöneticilik yapar” ifadesine katılım oranı \% 64' dür.

Kadınların lider olarak algılanmaması takipçilerin liderliğe ilişkin zihinsel şemaları ile ilgilidir. Takipçilerin zihinlerinde liderliğin erkeksi tutum ve davranışlarla özdeşleşmiş olması kadınların lider olarak algılanmasının önüne geçmektedir (Cengiz ve Özdemir, 2020; Rosette ve Tost, 2010). Yukarıda da belirtildiği üzere kadın liderlerin sayısı kamusal alanda giderek artmaktadır. Özellikle muhtarlık bağlamında düşünüldügünde kadın muhtarların liderlik stillerini nasıl kurguladıkları önemli bir çerçeveyi oluşturmaktadır çünkü bir erkek lider ile karşılaştırıldığında kadın liderin aşması gereken ilk engel takipçilerin zihinlerindeki liderlik şemasına ilişkin olmaktadır.

Hearn (2004), hegemonyanın kolektif siyasal aktörler ağ 1 içinde de işlediğini ifade etmiştir; dolayısıyla bu siyasal ağ içerisinde kadın olmanın ve lider olarak ortaya çıkmanın bireysel birçok çabayı gerektirdiğini tahmin etmek zor değildir. Toplumsal yapının biçimlendirdiği ve biyolojik farklılığa indirgenen bu cinsiyetçi tutum, kadını anne olmak, şefkatli olmak, itaat etmek, 1lımlı olmak rolleri ve özellikleriyle biçimlendirmektedir (Feather ve Boeckmann, 2007; Rudman ve ark., 2012). Bu biçimlendirme kadının yüksek statülü, onu görünür kılacak rol ve pozisyonlardan uzak durmasına sebep olmaktadır (Grijalva ve ark., 2015). Güç ve statü gerektiren liderlik rollerini yerine getiren kadın ise kabul ve onay almak için daha fazla erkeksi tavırlar ve tutumlar içerisine girebilmektedir. Ayrıca kadınların çoğu zaman görev rol ve sorumluluklarının dışına taşarak, aşırı çalışarak kabul alanını yaratmaya çalıştığı görülmektedir. Bu çalışmanın tasarlanmasındaki temel motivasyon, kadın muhtarların liderlik stillerini mesleki rolleriyle nasıl birleştirdiklerini görmek ve bu birleşimde katılımcı liderliği 
benimseyip benimsemediklerini ve katılıma dair anlayışlarını ortaya çıkarmaktır. Otoriter, demokratik, bırakınız yapsıncı vb. gibi lider tipleri arasında katılımcı liderliğin bu çalışmada seçilmesinin iki sebebi bulunmaktadır. Birincisi muhtarlık görev ve rolleri başta mahalle sakinleri olmak üzere birçok kamu-özel kurum ve kuruluşlarla katılımı inşa eden ve sürdüren bir yapı gerektirmektedir. İkincisi kadınların bu liderlik tarzıyla mesleki amaçlarına daha kolay ulaşacağını varsaymamızdır. Takipçileri ile güçlü, dürüst, güvene dayalı ilişkiler kurabilmek için katılımcı liderlik özellikle muhtarlık mesleğinin özellikleri düşünüldüğünde daha önemli olmaktadır. Çünkü liderliğin özünde takipçilerle kurulan yapıcı ve işbirliğine dayalı ilişkiler bulunmaktadır. Bu ilişkilerin zayıf olması durumunda liderin "lider" olarak algılanma olasılığı çok düşüktür (Joseph, 2016).

Katılımcı liderliğin 1938'de Barnard'dan günümüze artan önemi, bu tarz bir liderliğin takipçilerinde yarattığı içsel motivasyon ve güvenle güçlü bir ilişki içinde olmasından kaynaklanmaktadır. Liderin alacağı kararlardan en çok etkilenecek olan kişilerin ister çalışan ister mahalle sakini olsun, karar alma süreçlerinde bilgisine, görüşüne danışılan aktörler olmaları onların hem lidere hem de alınacak karara daha çok sahip çıkmasını sağlamaktadır (Harman, 1981). Katılımcı liderlik, aynı zamanda farklı sosyal ağlarda, doğrudan veya dolaylı bağlantılar sayesine yeni bilgilere ulaşmayı sağlar; alınan bilgiler ise liderin amaçlarına ulaşmasını kolaylaştırır. Özellikle Türkiye gibi düşük sosyal sermaye profiline sahip bir ülkede (Sargut, 2007), bireyler ve kurumlara olan güvenin çok düşük olduğu göz önünde tutulduğunda (Bkz. Ataseven, Akış ve Keyman, 2018; Ertan, Aytaç ve Çarkoğlu, 2019; Esmer, 1999), sosyal ağlara ulaşmak ve bu ağlarda yer alan bilgi gibi kaynaklardan faydalanmak daha da zor olmaktadır. Bu süreçte katılımcı liderlik tarzı sergilemek, muhtarların yetkili oldukları mahallelerin sorunlarını çözmek için ilgili kişi ve kurumlarla ilişkili sosyal ağlara ulaşmalarını kolaylaştırabilecek bir işleve sahip olabilir. Demokrasi ve çoğulcu temsilin güçlenmesini de sağlayan katılımcı liderlik, karar alma süreçlerine katılımın önünü açabilecek bir role de sahiptir. Bu nedenle katılımcı liderlik karar alma sürecinde yaratılan "ortak etki" olarak tanımlanmaktadır (Bkz. Somech, 2003, s. 1003). Örneğin Lüchmann'ın (2017) araştırmasında Brezilya' da katılımcı bütçeleme sürecinin demokrasinin gelişimindeki rolünü bilimsel verilerle görmek mümkündür. Dolayısıyla bu çalışmada öne çıkarılan ve kadın muhtarlar nezdinde incelenen katılım, Hogwood ve Gunn'1n (1984, s.108) tanımladığı üzere, kamu politikasının amaçlarını, kapsamını, tasarımını ve uygulanmasını etkilemek için bireyler ve gruplar tarafından kullanılan tüm 
resmi ve gayri resmi araçlar olarak ifade edilmiştir. Bu resmi ve gayri resmi araçların kullanımının nasıl olacağı liderlerin katılımcı liderlik modelinde deneyim kazanmasına bağlıdır. Liderliğe ilişkin durumsallık yaklaşımları incelendiğinde içinde bulunulan çevre, karar alınacak konu, takipçilerin özellikleri gibi kriterler her birey ve grup için tek bir katılımcılık stilinin olamayacağını göstermektedir (Bkz. Rogiest, Segers ve van Witteloostuijn, 2018; Somech, 2003). Bu çalışmada ise kadın muhtarların mesleki rollerini yerine getirirken hangi konularda, kimlerle ve hangi kurumlarla nasıl bir katılımcı liderlik modeli benimsediğini keşfetmek amaçlanmıştır.

\section{Araştırma Yöntemi}

Gerçek dünyada doğal olarak ortaya çıkan durumları anlamak için katı araştırma desenlerinden ziyade zengin ve aydınlatıcı bilgiye ulaşmak için bu çalışma uygulamalı nitel araştırma olarak tasarlanmıştır. Nitel araştırma, olayların ve olguların bağlantılı olduklarını ve kesin sınırlarla ölçülemeyeceğini varsaymaktadır. Bu yüzden nitel araştırmalar için "algıların ve olayların doğal ortamda bütüncül bir biçimde ortaya konmasına yönelik bir süreç” tanımlaması yapılmaktadır (Yıldırım ve Şimşek, 2011, s. 39). Nitel araştırma tasarımının temellendirilmesinde farklı yaklaşımlar olmakla birlikte (Creswell 2016, s. 6; Maxwell, 2018, s. 43; Patton, 2018, s. 15), bu çalışmada durum çalışmasının kullanılması tercih edilmiştir. Bir durum çalışması, güncel bir olguyu (durumu) derinlemesine ve gerçek dünya bağlamında araştıran bir yaklaşımdır; durum ve bağlam arasında sınırların net olmadığı ve "nasıl?", "neden?” sorularına yanıt arandığı araştırma tasarımlarında durum çalışması işlevsel olmaktadır (Yin, 2015, s. 45,61). Durum çalışması ile sosyal bağlamın parçası olan karmaşık ve biricik durumdan sosyal davranışın kavramsallaştırılması mümkün olmamaktadır (Glesne, 2016, s. 30-31). Alan yazınında durum çalışmasının üç türünden bahsedilmektedir. Bunlar; araçsal durum çalışması, içsel durum çalışması ve çoklu durum çalışmasıdır (Creswell, 2016, s. 99). Bu çalışmada, kadın muhtarların karar alma süreçlerinde katılıma ilişkin tutumlarını ve mesleki rollerini ortaya çıkarmayı amaçladığı için içsel durum çalışması yapılmıştır.

\section{Katılımcılar ve Veri Toplama Süreci}

Nitel araştırma yöntemi veri derinliğine odaklandığından ve genelleme amacı taşımadığından bu çalışmada amaçsal örneklem seçim tekniği kullanılmıştır. 
Çalışmayı yürüten kişilerden bir araştırmacının uzmanlık alanı gereği evrenin özellikleri hakkına bilgi sahibi olması, araştırma konusuna uygun olan evreni tipik temsil ettiği düşünülen amaçlı bir alt grubun örneklem olarak seçilmesini sağlamıştır. Kadın muhtarların katılım konusundaki tutum ve rollerinin araştırıldığı bu çalışmada Eskişehir ilinde görev yapan kadın muhtarlar çalışmanın örneklem grubu olarak seçilmiştir. Türkiye Muhtarlar Konfederasyonu'ndan elde edilen verilere göre Eskişehir'de görev yapan 30 kadın muhtar bulunmaktadır. Amaçlı örneklem yöntemlerinde örneklem büyüklüğü, veri toplama esnasında araştırmacının karşılaştı̆̆ durumlar ve araştırmaya yönelik ilk düzey bilgilendirici değerlendirmelerle belirlenmektedir. Eğer amaç, bilginin maksimum derecede elde edilmesiyse, yeni örneklem birimlerinden artık yeni bir bilgi gelmediği noktada, yani doyum noktasında, örnekleme dâhil etmeler durdurulur; yani bilgilerin tekrarlanması ilk ölçüttür (Shenton 2004'dan akt. Baltacı, 2018, s. 261). Bir diğer ifadeyle bu çalışmada amaç bilgiyi artırmak olduğundan, örneklem birimlerinden yeni bilgi gelmediğinde doygunluk ve aşkınlık temel ölçütleri dikkate alınarak, görüşmelere devam edilmiştir. Bulgularda tematik ve sistematik tekrarlar belirlendiğinde görüşmeler 11 kadın muhtara ulaştığında sonlandırılmıştır. Görüşmeler, Mayıs-Haziran 2020 aylarında pandemi sürecinde olunduğundan yüz yüze yapılamamıştır; internet ortamında gerçekleştirilen 4 görüşme, katılımcıların onayı ile ses kaydı alınarak yarı-yapılandırılmış görüşme türünde gerçekleştirilmiştir. Diğer 7 görüşme ise internet bağlantısı sağlanamadığından, yazılı olarak yapılandırılmış görüşme türünde gerçekleştirilmiştir. Betimsel ve sistematik analizi yapılan 4 görüşmenin en kısası 40 dakika, en uzunu 95 dakika sürmüştür; bu görüşmelerin sonucunda 4 saat 8 dakikalık ses kaydı elde edilmiştir. Geri kalan 7 görüşme ise toplam 11 sayfadan oluşmaktadır. Yüz yüze görüşme yapılamaması, araştırmacıların betimsel çözümlemede önemli olan -bağlam- hakkında gözlemlerini sınırlandırmış, yazılı yapılan görüşmeler ise ihtiyaç duyulduğunda derinlemesine ilerleme avantajını kaybettirmiştir. Yarı yapılandırılmış bu görüşmelerde aşağıdaki soru çizelgesi kullanılmıştır:

1.Neden muhtar olmak istediniz? Bu kararı vermenizde etkili olan kişiler kimlerdir?

2.Mahalleniz adına şimdiye kadar çözdüğünüz sorunları/kararları düşündüğünüzde, bunlar arasında yoğun çaba gösterdiğiniz ve kapsamlı düşünmenize sebep olan karar örnekleri neler? 
3. Bu sorunu çözme ya da kararı verme sürecinde hangi adımları attınız?

4.Arac1, temsilci, köprü, lider? Bu kavramlardan daha çok hangisi sizi anlatıyor? Kısaca açıklar mısınız?

5.Mahallenizde mahalle meclisi var mı? Varsa başkanı kim? Meclisin faaliyetleri ya da aktif katılımı hakkında neler düşünüyorsunuz?

6.Belediyenin stratejik planlama sürecine ve bütçe hazırlama süreçlerine kat1lım gösterdiniz mi?

7.Kent yönetiminde yeterli düzeyde söz sahibi olduğunuzu düşünüyor musunuz? Bu ilişki hakkında ne düşünüyorsunuz?

Örneklem Türkiye'deki tüm kadın muhtarları temsil etmemektedir; bununla birlikte görüşmelerin üçte ikisi bittiğinde verilen yanıtlarda sistematik tekrarlar gözlemlenmeye başlanmıştır. Bu açıdan benzer özellikler gösteren bağlamlar ve örneklemler söz konusu olduğu takdirde verilerin nitel araştırmalarda transfer edilebilirlik kriterini sağladığı söylenebilir. Bulgulara ilişkin yorumlar metin içinde görüşmecilerin kendi ifadeleri ile desteklenmiş, iki kadın muhtar ile yazılı olarak paylaşılmış, ve bu metinler kadın muhtarlar tarafindan onaylanmıştır. Bu bakımdan araştırmanın nitel araştırmalarda inandırıcılık ve doğrulanabilirlik kriterlerini yerine getirdiğini söylemek mümkündür. Örneklemdeki kadınların demografik bilgilerini Tablo 1'de görmek mümkündür.

Tablo 1

Katılımcıların Demografik Bilgileri

\begin{tabular}{lcccc}
\hline & Yaş & Medeni Durum & Eğitim Düzeyi & Görev Süresi \\
\hline K.1 & 52 & Evli & Lisans & $1 \mathrm{y} 1 \mathrm{l}$ \\
K.2 & 46 & Evli & Lise & $1.5 \mathrm{y} 1 \mathrm{l}$ \\
K.3 & 43 & Evli & Ortaokul & $1 \mathrm{y} 1 \mathrm{l}$ \\
K.4 & 52 & Evli & Lisans & $6 \mathrm{y} 1 \mathrm{l}$ \\
K.5 & 50 & Evli & Lisans & $6 \mathrm{y} 1$ \\
K.6 & Evli & Lise & $1.5 \mathrm{y} 1 \mathrm{l}$ \\
K.7 & 46 & Boşanmış & Lise & $7 \mathrm{y} 1 \mathrm{l}$ \\
K.8 & 46 & Evli & Lise & $1.5 \mathrm{y} 1$ \\
K.9 & 56 & Evli & Lise & $12 \mathrm{y} 1 \mathrm{l}$ \\
K.10 & 57 & Bekâr & Yüksekokul & $1.5 \mathrm{y} 1 \mathrm{l}$ \\
K.11 & 43 & Dul & Lise & $11 \mathrm{y} 1 \mathrm{C}$ \\
\hline
\end{tabular}




\section{Verilerin Analizi}

Verilerin betimlenmesi ve temaların oluşturulmasında içerik analizi yaklaşımı benimsenmiştir. İçerik analizinde temel amaç elde edilen verilerdeki benzerliklerden yola çıkarak kavramları ortaya çıkarmak ve okuyucuya düzenli ve anlamlı bir şekilde bilgi sunmaktır (Yıldırım ve Şimşek, 2011, s. 227).

Strauss ve Corbin (1990) üç tür kodlama biçiminden bahsetmektedir. Buna göre, verileri toplamadan önce araştırmanın temelini oluşturan kavramsal çerçeveye uygun kod listesinin yapılması veya temaların belirlenmesi durumu mümkündür. Bu tür kodlama birinci tür kodlamadır. Bu durumda verilerin kodlanması daha kolaydır ve belli temaların altına kodlamalar yapılabilir. İkinci tür kodlama ise verilerden çıkarılan kavramlara göre kodlamadır. Buradaki amaç toplanan verilerden bir çerçeve oluşturmaktır. Üçüncü tür kodlama diğer iki tür kodlama biçiminin birleşmesidir. Belli bir kavramsal çerçeveye göre analiz yapılsa da ortaya çıkan yeni kodlar kod listesine eklenmektedir (Y1ldırım ve Şimşek, 2011, s.231-232). Bu araştırma, katılımın yönetim felsefesine dayanmakta ve üçüncü tür kodlama biçimini yansıtmaktadır. Öncelikle kodlamalar yapılmış ve yeni bulunan kodlamalar da listeye ilave edilerek temalar oluşturma yoluna gidilmiştir. Kodlayıcıların cevaplarındaki kararlılık anlamına gelen güvenilirlik (Creswell, 2016, s. 253) için kodlayıcılar arası görüş birliği kullanılmıştır (Miles ve Huberman, 2016, s. 64).

\section{Bulgular}

\section{Kadın İşi” Muhtarlıktan Mahallenin Anneliğine Giden Meslek ve Rol Algısı: ANACAN Muhtarlar}

Örneklemdeki tüm kadın muhtarlar, muhtarlığın gerektirdiği kişisel özellikler ile kadınlara atfedilen özellikleri birleştirdiklerinden, bu işin kadınlar tarafından yapılması gerektiğine inanmaktadırlar. Muhtarlığın disiplin, azim, iletişim becerisi, güler yüz, tatlı dil, sabır, samimiyet gibi özellikler gerektirdiği ve kadınların bu özelliklere sahip olmalarından dolayı kadın olmanın bu mesleği yaparken dezavantaj değil, avantaj oluşturduğunu ifade etmişlerdir:

"Kadınların daha çok olması gerekir. Kadın anaç, bilgili, kafasına takınca çözünceye kadar bırakmıyor. Çok memnunum, kadınların olması çok hoşuma gidiyor, daha da fazlalaşmamız gerekiyor.’(G.6) 
“Tüm muhtarların kadın olmasını isterdim, kadınlar daha disiplinli, daha azimli.”(G.1)

"Kadın muhtar olmak güler yüz, samimiyet, açık yüreklilik, hassasiyet, gözlemcilik, gerektiğinde anne gerektiğinde liderlik vasfını kullanmak demek."(G.4)

“...sabırlı ve tutarlı olacaksınız ki karşınızdaki kişiye nabzına göre şerbet vereceksiniz... Bir takım vaatlerle gideriz, şunu yaparım, bunu yaparım diye. O yüzden o sözleri tutmamız mutlaka gerekiyor... Ama kesinlikle sabır ve tutarl1l1k gerekiyor."(G.5)

“İnsanların ilk önce aradıkları şey güler yüz, eğer o insanlara güler yüzlü davranıyorsanız, sıcak davranıyorsanız, bütün problemleri çözebiliyorsunuz zaten. Mesela sinirli bir şekilde gelebiliyorlar yanınıza, ama biz onları öyle bir kıvama getiriyoruz ki, çok teşekkür edip tekrar geri gidiyorlar... Özveri isteyen bir meslek muhtarlık..."(G.6)

"Kadın olmak zaten bir ayrıcalık. Ayrıca her ortama ayak uydurmak daha kolay oluyor. Ayrıca herkes yaşlısından çocuğuna, kadınından erkeğine herkes istediği zaman sana ulaşabiliyor.'(G.11)

Fine (2011)'nın Toplumsal Cinsiyet Yanılsaması kitabında ifade ettiği gibi toplumsal cinsiyet kalıpyargıları, örtük zihinlerde örtük çağrışımlar barındırmaktadır. Bu örtük çağrışımlar, muhtarlık görev ve rollerinin eş ve anne olmak üzerinden ailecilik bağlamında inşa edildiğini göstermektedir. Bu konuda katılımcıların ifadeleri şu şekildedir:

“...sorunları kadın gözüyle görmek, kadın hassasiyetiyle çözebilmek için... Bir evin hâkimiyetini, düzenini nasıl ki kadın sağlıyorsa, bir mahallenin ihtiyacını, eksiklerini de kadınlar daha iyi bilir ve hızlı çözüm üretir...’(G.2)

“Kadınlarımızın azimli, çalışkan ve kararlılıklarının yanında, bir anne sevgi ve şefkati ile yaklaşmaları... Asla karşı cinse yarış içinde olmadım.”(G.3)

"...mahallenin muhtarı olmak istiyorum ama karşımda kadın rakibi olan tek muhtar benim bu arada... İlk seçimimde aldım. Ama ben bunda en büyük etkenin dediğim gibi aile durumumun düzgün olması, bir de yazdığım mektup diye düşünüyorum..."(G.5) 
“...insanlar mesela kadın muhtar, erkek muhtarlarımız yanlış anlamasınlar, daha anaç oldukları için şimdi bir kişi geliyor, daha rahat anlatıyor, yani sıkıntısını, derdini. Daha kolay anlatabiliyor bize... O güveni karşı tarafa vermek söz konusu. O güveni verdiyseniz kadın erkek fark etmiyor. Bacım diyor, kardeşim diyor. Onlar bizim abimiz, ablamız, kardeşimiz, her şeyimiz. Yani biz de bu şekilde elimizden geldiği kadar destek olmaya çalışıyoruz.”(G.6)

"Ben tam bir... (katılımcı burada adını söylemiştir) anasıyım. Yani orası benim evim ve çocuklarım... Kiminin annesi oluyorum, kiminin kardeşi, kiminin bacısı oluyorum, kiminin yoldaşı..”(G.8)

Kadın muhtarların mesleği annelik üzerinden algılamaları onların görev ve sorumluluk alanlarını da değiştirmişstir. Bu durum, mahalle sakinleriyle kurdukları ilişkide profesyonel unsurlar kadar Türk toplumunun taşıdığ1 kolektivist ve dişil değerlerin etkisiyle, ilişkisel unsurların ağırlıklı olmasına yol açmıştır. Paternalist liderliğe annelik rollerinin bezenmesiyle birlikte muhtar-mahalleli ilişkisine bu liderliğin himaye altına alma-özel sorunlarla ilgilenme boyutlarını getirmiştir. Muhtar rol ve sorumluluklarının duygusal emek barındıran toplumsal cinsiyet rolleri ile iç içe girdiğini görmek mümkündür. Konuya ilişkin aşağıdaki katılımcı ifadeleri şu şekildedir:

“...yani bir şeye ihtiyacı var insanların ve size geliyorlar, size derdini anlatmak istiyor. Bazen terapi gibi geliyorsunuz siz onlara. Onların dertleri ile üzüldüğünüz zamanlar oluyor... Bazen terapist, bazen sosyal yardım vakfı gibi çalışıyorsunuz..."(G.7)

“...Covid-19 döneminde... İhtiyarların alışverişinin yapılması, bankadan paralarının çekilmesi, hastaneye götürülmesine kadar, vefa grubu var ama mahallenin vefası benim... Yaşlılar telefon açıyor, kızım maaşımı çekemedim diyorlar... Ben sana güveniyorum nafakamı da öde diyorlar... Bir tanesi kızım marketten 2 kilo soğan, 3 kilo... al diyor. Ya sen de olmayacak işlere koşuyorsun diye sitem eden arkadaşlarım oldu ama ben o kadar mutlu oldum ki anlatamam yani." (G.5)

“...Bence muhtarlıkta en güzel şey kalbe dokunmak. Çünkü yolu yaparsınız, elektriği getirirsiniz, otobüsü getirirsiniz, parkı getirirsiniz ama şuraya girmek çok önemli. Ben buraya girmeyi başardım. Gönüllere girmeyi başardım. Dedim ya her eve, yaz-kış 14 aydır görevdeyim, 14 aydır daha bir gün ekstra böyle 
koltuğuma yaslanıp “Oh be! Bugün de böyle bir yatayım.” dediğim günüm olmadı benim. Yapı olarak da zaten olmaz. Eve geldiğimde de gece 3'e kadar çalışırım. Alırım elime bütün kâğıtlarımı yarın ne yapacağım, kime gideceğim, ne soracağım, Ayşe'nin ne derdi vardı, Fatma'ya ne lazımdı? İnsanların kişisel sorunları ile de ilgileniyorum... Adamın karısı kaçmış, bana geliyor, muhtarım karım kaçtı, benim karımı bul gel, diyor. Oğlu okulu bırakmış, okulu bırakanlar, muhtarım bir gel konuş diyor. İşten, fabrikadan atılmış, muhtarım ne olur, fabrika sahibi ile bir görüş diyor. Bunların hepsini yapıyorum, gidiyorum, konuşuyorum, görüşüyorum..." (G.8)

Örneklem genelinde kadın muhtarların tatlı dil, güler yüz, samimiyet gibi kadınlara atfedilen ve kadınlardan beklenen davranış normları ile muhtarlık mesleğini birleştirdikleri görülmüştür. Türkiye'de sıklıkla görülen paternalistik liderliğin anne şefkati ile kurgulandığı bu meslekteki görev ve rol algıları da profesyonel iş tanımlarının dışına taşarak, bire bir ilişkilerin doğurduğu yeni ilişkisel görev tanımlarını eklemiştir.

\section{"Sevgili Eşim" ve Aile Desteği}

Örneklemdeki kadın muhtarların çoğu muhtar olma kararını almalarında başta eşlerinin olmak üzere aile üyelerinin desteğine sık sık ifadelerinde yer vermişlerdir:

“...Yerel yönetimlerde kadınların daha başarılı olacağını düşündüğüm için aday oldum. En büyük destekçim eşimdi... İlk önce ailemin desteği ve anlayışı önemli... Benim muhtar olmam için gerekli şartları sağlayan ve eşitlik ilkesine inanan, beni destekleyen eşim ve ailem var. Ne olursanız olun, Cumhurbaşkanı da olsanız, anneyseniz önceliğiniz o oluyor. Yetişemediğimde yetişen bir eş ve sizi anlayan çocuklar var ise dengeyi sağlayabiliyorsunuz...” (G.4)

“Öncelikle ailem çok destek oldu. Eşim, kızlarım çok destek oldular... Ailemde takım çalışması var zaten.” (G.5)

“Eşim, dostum, arkadaşlarım 'gel, muhtar ol' dediler. Ailece, eşimle, oğlumla konuştuk, karar verdik. Onlar benim her konuda çok destekçim, onlarla karar verdik, adaylığımı koydum.” (G.6)

“...Bu kararı vermemde en büyük etken çevrem, komşularım ve ailemdir." (G.2) 
Katılımcılardan sadece bir tanesi eşinden ayrılmıştır. Onun bu soruya yanıtı diğer katılımcıların yanıtlarından daha farklıdır:

“... kendi başına karar veren bir insanım. O dönemde eşimle birlikteydik, 20 yıllık evliydik. O bana şey dedi, 'Napacaksın, çok uğraşırsın, çok zor bir iş insanlarla uğraşmak’ falan gibi. O çok taraftar olmadı işin aslı. Sonra ben kendi kendime karar verdim, seçimlere katıldım.” (G.7)

Yüce Tar'ın (2016) çalışmasında da Samsun ilinde kadın muhtarların bu mesleği seçmelerinde eşlerinin desteğini çok önemsedikleri ve bu destekle yola çıktıkları bulgusuna yer verilmiştir.

\section{Liderlik Stili ve Katılımcı Liderlik}

Katılım ve muhtarlığın -aracı olma- rolü ile nasıl birleştiğine dair katılımcı ifadeleri şu şekildedir:

"Mahallemin kent pazarı talebini belediyeler ve pazarcılar odası başkanına ilettik." (G.2)

"Mahallemin enerji nakil hatları sorunlarını çözmek için enerji yetkilileri, kaymakam ve belediyelere gittim." (G.3)

“...bizim mahallemiz afetli riskli alan ilan edildi... Siyasi partilerin biz hepsiyle görüştük. Milletvekillerinin hepsiyle görüştük. Belediye başkanımızla görüştük. Tabii bu işin içinde Çevre Şehircilik Bakanlığı da var. Mesela benim mahallemde bir mağdurlar derneği kuruldu. ... işte dernek kuruldu ve mahalle sakinleri dernekle birlikte hareket etti." (G.7)

"Benim kaymakamla, valilikle, belediyeyle... Zaten ben konuşan bir insanım, hep de gülerim konuşurken... İnsan ilişkilerim de çok iyi. Sağ olsunlar, onlar da hep bazen bir dilekçeye bile gerek kalmadan işlerimi çözümlüyorum.” (G.6)

“...(katılımcı mahallesinin adını söylemiştir) zaten gariban bir mahalle. Kimin kapısını çalacaksın da kimden destek alacaksın? Onlar zaten bana sığınmışlar. Ee şimdi böyle olunca da ne oluyor, yine top bana kalıyor ve ben çevremi kullanıyorum. Geçmişte hep birlikte olduğum için, o insanlar benim bu kadın kurulu başkanlığından dolayı ben zaten Vali Bey, Kaymakam Bey, belediye başkanları, milletvekilleri, meclis üyeleri, üst düzeydeki iş adamları, fabrikatörler zaten bunlarla hep ben toplantılarda yan yana iç içe olduğum için, 
ben zaten onların içinden gelen bir insan olduğum için, kapılarını çalmakta zorlanmıyorum. Yani gittiğimde bizim... (katılımcı adını söylemiştir), diye karşılanıyorum.” (G.8)

$\mathrm{Bu}$ ifadeler, örneklemdeki kadın muhtarların katılımcı liderlik davranışlarını sınırlı bir alanda, aracılık rolü ile karışık bir şekilde sergilediklerini düşündürmüştür. Kadın muhtarların mahalle sakinleriyle çoğunlukla yüz yüze sohbet ortamında, tatl1-sert, güler yüzlü gibi feminen özelliklerle iletişim süreci yürüttükleri fikrine varılmıştır. Bu konuda bazı katılımcıların ifadeleri şu şekildedir:

“...Mesela bizim ülkemizde kim ve nasıl bir uygulama ile kıraathaneleri erkeklere tahsis ettiyse, ben kadın muhtar olarak arada sırada akşamları mahallemin kıraathanelerine giderek, çay içerim ve mahallenin erkek sakinleri ile sohbet ederim..."(G.4)

"Bazen uzlaşmacı bazen otoriter olmak zorunda kalıyorsunuz. Bu biraz kadın muhtar olmakla da alakalı... Kadın olduğumuz için biraz daha dikkatli olmak zorunda kalıyorsunuz. Bazı yerlerde otoriter davranmak zorunda kalıyorsunuz... En son emniyet müdürlerinden birine ben dedim ki, 'müdürüm, siz hanımefendi, zarif olmayı zayıflık olarak mı algılıyorsunuz acaba, benim işim böyle aksadı' dedim."(G.7)

“...Yerine göre tatlı dilden anlamıyor, sert olmak zorunda kalıyorsunuz. Çayım hep kaynar, kahveni içmeye geldim diyen çok fazla...” (G.5)

"Dominant biliyorlar aslında çok merhametliyimdir, inanılmaz derecede hassasımdır. Ama dik ve sert görünmek zorundayım. Çok aşırı derecede aslında vicdanlıyımdır. Çok çabuk yumuşarım aslında ama dik görünmek zorundayım. Çünkü böyle dik görünmezsem bazı şeyleri yaptıramam. Ama karşımdaki insana kızarım, mesela sert yaparım, ama onun işini hallederim de ona yapacağımı söylemem." (G.8)

\section{Mahalle Ölçeğinde Katılım Sağla(ya)ma(ma)}

Katılımcıların bir kısmı mahallelerinde mahalle meclisinin bulunduğunu belirtmiştir. Bir kısmı ise mahalle meclisine gerek duymadıklarını ve hatta mahalle meclisi kurmadıklarını ifade etmişlerdir. Bu durumda katılımcıların mahalle meclisinin kuruluşu, işlevi gibi konular yanında katılımcı süreçler 
içinde mahalle meclislerinin rolleri hakkında yeterli bilgiye sahip olmadıkları sonucuna erişilmiştir. Bu konuda katılımcıların ifadeleri şöyledir:

"Mahalle meclisi adı altında bir oluşum oluşturmadım. Azalarımla, cami dernek başkanlarıyla, site yöneticileri ve esnaflarla iletişim içerisindeyim”. (G.2)

"Mahalle meclisi yok. Kurulması taraftarı değilim. Siyasal yapı içindeler." (G.3)

"Mahalle meclisimiz yok. Ben ona ihtiyaç duymuyorum." (G.8)

"Mahalle meclisimiz var ama faal değil. Muhtar olduk hemen bir sene içinde oldu." (G.5)

Katılımcılardan iki tanesi mahallelerinde mahalle meclisi olduğunu ve başkanlığını kendilerinin yürütmediğini ifade etmişlerdir:

"Uzun zamandır bir mahalle meclisi isteniyordu. Onu kurduk. Çok da güzel bir ekibimiz oldu. Onlar da çok yardımcı oluyorlar sağ olsunlar. Bu şekilde çalışmalarımızı götürüyoruz.” (G.6)

"Mahalle meclisimiz vardır. Başkanı... (katılımcı meclis başkanının adını söylemiştir). Meclisimiz 2014 y1lında kurulmuştur... İlk dönemki gibi aktif olunmasa da mahalle meclisi çalışmalarını sürdürüyor.” (G10)

Katılımcılardan iki tanesi mahalle meclislerine kendilerinin başkanlık ettiğini belirtmiştir. Söz konusu katılımcılardan biri mahalle meclisi ile ortak kararlar aldığını belirtmiştir:

"Mahallemde mahalle meclisim var... Başkanlığını muhtarlık adına ben yapmaktayım... Meclisin faaliyetleri ilk yılardaki kadar aktif olmasa da devam etmektedir. Katılım biraz sorunlu olmakta, insanların vakit ayırmakta zorlandıkları gözlemlenmektedir”'(G.9)

"Evet, mahalle meclisim var. Başkanı benim ve azalarım ile birlikte mahalle sakinlerinin katılımları ile ortak kararlar almaktayız. Mahalle meclisi kurarak mahalle sakinleri ile ortak karar alma ve fikir alışverişinde bulunmaktayım. Şu anda 1000 kişinin ekli olduğu bir whatsapp grubum var. Her türlü bilgileri paylaşmaktayım.” (G.4) 
Katılımcılar mahalle ölçeğinde alınması gereken kararları katılımcı süreçler oluşturarak almamaktadırlar. Ancak dikkat çekicidir ki bir sonraki bölümde yer verilen ifadelere de bak1lacak olursa muhtarlar kent yönetiminin daha katılımcı olması gerektiğini savunmakta ve kendilerinin karar alma süreçlerine daha fazla dâhil olmaları gerektiğini ifade etmektedirler. Örneğin, bir katılımcı kent yönetiminde daha çok söz sahibi olmaları gerektiğini çünkü her bir muhtarın kendi mahallesini çok iyi bildiğini ifade etmiştir. Yine bir başka katılımcı, belediye meclislerinde kendilerine de yer verilmesi gerektiğini dile getirmiştir. Ayrıca katılımcıların özellikle mahalle meclisleri hakkında yapmış oldukları yorumlar katılımcı süreçler ve bu süreçlerde yer alan aktörlerle ilgili yeterli bilgiye sahip olmadıkları izlenimi oluşturmuştur.

\section{Etkisiz Yetkili Kadın Muhtarlar}

Katılımcılar görevlerini yerine getirirken deneyimledikleri süreçler çerçevesinde kendilerinin kent yönetimine yeterli oranda katılım sağlayamadıklarını ifade etmişlerdir. Katılımcılar gerçekleştirmekte oldukları görevler, mahallelerine yönelik çalışmaları ve mahallelerine dair aidiyet algıları doğrultusunda karar alma süreçlerinde daha etkin olmak istediklerini ve hatta söz konusu karar alma süreçlerine katılımlarının bir "hak" olarak tanınması gerektiğini belirtmişlerdir. Bu konuda katılımcıların ifadeleri şöyledir:

"Halkın özgür iradesi ile seçilen ve demokrasinin temel taşı olan muhtarlık kurumuna gereken önem verilmemektedir. Elimizdeki yetkiler alınarak bizler sadece danışma memuru gibi görev yapmak zorunda bırakıldık. En azından birkaç arkadaşımızın belediye meclislerinde görev alması gerekir. Halkın içinden halk ile birlikte iç içe olan muhtarların mahalle sorunlarını dile getirmesi önemlidir." (G.4)

"Biz muhtarların adı var da kendi yok aslında. Muhtar muhtar diyorlar da, bu sene siz de görmüşsünüzdür, çok da yetkileri yok aslında. İnsan ilişkilerini güzel tutup, onların isteklerini yaptı̆̆ınızda mahalle ile olan ilişkilerinizi yönetebiliyorsunuz. Mahalleli sizi seviyor, tutuyor. Benim bir devlet kurumuna şunu şöyle yapın deme hakkımız yok." (G.5)

"Kent yönetiminde daha çok söz sahibi olmamız gerektiğini düşünüyorum. Çünkü biz kendi arkadaşlarımız arasında da değerlendiriyoruz bunu. Herkes kendi mahallesini iyi biliyor ve bu şekilde olursa daha güzel olacağını 
düşünüyorum.” (G.6)

"Kanunda mahallenin mülki amiri diye geçiyor. Ama bana göre değil. Çünkü muhtarın hiçbir yetkisi yok şu anda... Benim mahallemin şuna ihtiyacı var gelin bunu yapın diyemiyorsunuz. Ricacisınız siz, ricac1, aracı kurum. Yani yetki yok. Etkisiz yetkili. Öyle diyorum ben." "Yetkilerin kesinlikle arttırılması gerek. Yani bu tespitler yapılırken (ihtiyaç sahiplerine yapılacak yardımlardan söz ediliyor) falan da muhtarların bir yetkisi olması gerekir diye düşünüyorum ben. Bu adres beyanlarında olduğu gibi." (G.7)

"Mahallemi benden iyi kim bilebilir... Şöyle bir şey, muhtarların daha çok hak sahibi olması gerektiğini düşünüyorum. Çünkü ben, olağanüstü çalışıyorum. Kendi adıma söylüyorum. Benim mesai saatim 5 değil, bazen 9, bazen 10, bazen 11, bazen gece saat 3'e kadar... Bence muhtarların daha çok masada olmas1 gerekiyor.“(G.8)

“Kent yönetiminde maalesef yeterli düzeyde söz sahibi değiliz... Belediye meclislerinde hangi mahallenin sorunu görüşülecekse o mahallenin muhtarının da bir oy sahibi olarak görüş bildirmesi gereklidir.“(G.9)

"Kent yönetiminde yeteri kadar sözümüzün geçtiğini düşünmüyorum. Belediye meclislerinde bizlere de yer verilmesi gerektiğini düşünüyorum.“ (G.10)

\section{Sonuç ve Değerlendirme}

Bu çalışmada kadın muhtarların mesleki rol ve katılıma ilişkin algıları onların gözünden betimlenmiş, öne çıkan temalar doğrultusunda kadın muhtarların mesleklerine ilişkin rol ve davranışları katılım ve liderlik perspektifiyle değerlendirilmiştir.

Kadın muhtarlar, kadın olmaya atfedilen özellikleri sahiplenmekte ve mesleklerini yaparken geliştirdikleri davranışlara bu özellikleri yansıtmaktadırlar. Muhtarlık mesleğini yerine getirirken -mahalleM- diye adlandırdıkları yerde, mahalle sakinlerinin sorunlarına, mahallenin ihtiyaçlarına karşı geliştirdikleri tutum ve davranışlarda anne şefkatine sahip olmanın ve -kadın gözüylebakmanın onlar için bir avantaj olduğunu düşünmektedirler. Toplumsal cinsiyet kalıp yargılarının kadın olmaya atfedilen bakım sağlama, yetiştirme, sevgi ve şefkat sahibi olma gibi betimleyici özelliklerin (Spence ve Helmreich, 1978) 
kadın muhtarlar tarafından da mesleklerine yansıtıldığını görmekteyiz. Orhan, Palaz ve Altan'nın (2018) Bandırma'da kadın muhtarlar üzerinde yaptıkları çalışmada da kadınların evcillik ideolojisini içselleştirmelerinin doğal bir sonucu olarak bakım verme, yardımsever olma, şefkatli olma gibi özellikleri profesyonel mesleklerine taşıdıkları ve bu durumun onlar için avantaj yarattığını düşündükleri sonucu ortaya çıkmıştır. Türk toplumunun kolektivist özellikleri ve toplumsal cinsiyet rolleri birleştiğinde kadın muhtarların muhtarlık mesleğini yerine getirirken, resmi iş tanımlarının dışına çıkarak yeri geldiğinde dertleşilen, yeri geldiğinde bankadan para çeken anaç bir muhtar kadın profiline sahip oldukları görülmüştür. Bu durum ise Türkiye'de yaygın olan paternalistik liderlik modeliyle özdeşleşmektedir. Bu liderlik tipi, yazında baba figürüne benzetilmektedir; koruyan kollayan, himaye altına alan, aynı zamanda otoriter, hiyerarşik unsurları ilişkisinde barındıran bir lider tipidir (Aycan, 2006, 2015; Aycan ve Fikret-Paşa, 2003). Takipçilerinin özel hayatı ile ilgilenen, tavsiyelerde bulunan, kötü günde yardım eden bu lider tipi, Türkiye'nin ilişkisel ve geniş güç mesafesi ile paraleldir. Kadın muhtarların da mahallem diye adlandırdıkları yerde eşlerinin de desteğini alarak, mahalle sakinleriyle aralarında anne-çocuk ilişkisine benzer bir ilişki geliştirdiklerini gözlemlemek mümkündür. Benzer bir bulguya Yüce Tar'ın (2016) çalışmasında da yer verilmiştir. Mahallelerini genişletilmiş aile olarak gören kadın muhtarlar, kendilerini mahallenin anası olarak, mahalleyi ve mahalle sakinlerini de yardım edebilecekleri, iyileştirecekleri bir alan olarak görmektedirler.

Muhtarlık kurumunun temsilcileri olarak muhtarların gerek Kanun gerekse de mesleğin niteliği itibariyle toplumsal demokrasi ve sosyal sermayeyi geliştirmek için katılım esaslı bir yönetim anlayışına sahip olmaları gerekmektedir. Kadın muhtarların katılımcı liderlik süreçlerinden profesyonel anlamda faydalanmadıkları, mahallenin sorunları, ihtiyaçları çerçevesinde geliştirdikleri yönetim şeklinin katılımcı ilke ve aşamalardan uzak olduğu görülmüştür. Sorunları çözerken, çözümleri geliştirirken ilgili kişi ya da kurumlarla geliştirdikleri işlerde iletişim becerisi, ikna gücü, güler yüz gibi kişisel becerilerini kullanmayı tercih etmektedirler. Bu beceriler, liderlik anlamında ve amaçlara ulaşma noktasında tamamlayıcı liderlik unsurlarıdır; fakat söz konusu olan profesyonel yönetim olduğunda stratejik, vizyoner ve dönüştürücü bir performans benimsemek temel/olmazsa olmaz liderlik unsurlarıdır. Durumsal liderlik yaklaşımı çerçevesinde ve Kamu Yönetimi paradigmaları bağlamında katılımcı liderlik türü mahalle sakinleri-muhtar ve 
bürokrasi arasındaki üçlü yapının kurumsal ve sistematik bir işleyişe sahip olması açısından önemlidir.

Mahalle odaklı katılım açısından ele alındığında muhtarların mahalle düzeyinde karar alma süreçlerini katılımcı pratikler oluşturarak ve katılımcılığı teşvik ederek yönetmeleri gerekmektedir. Kadın muhtarların bu noktada kararları katılımcı bir şekilde almadıkları görülmüştür. Muhtarlar mahalleleri ile ilgili kararları alırken tek başına (ve belki bazen azalarıyla) hareket etmektedirler. Mahalle meclisinin bulunmadığı, aktif olmadığı birçok mahalle bulunmaktadır. Hatta muhtarların katılımcı süreçler ve bu süreçlerde rol oynayan aktörler ve işlevleri ile ilgili olarak da yeterli bilgi sahibi olmadıkları gözlemlenmiştir. Bu durumun en önemli göstergesi muhtarların mahalle meclisleri konusundaki yorumlarıdır. Mahalle meclisleri bazı muhtarlar tarafından oluşturulması keyfiyete ve şahsi tercihlerine bağlı kurumlar veya siyasi oluşumlar olarak algılanmaktadır. Diğer taraftan kadın muhtarların kent yönetimine yeterli düzeyde katılım göstermediklerini ifade ettikleri ve bu durumdan da yakındıkları görülmüştür. Söz konusu yakınma kendilerinin de mahalle düzeyinde katılımcı süreçler oluşturmadıkları olgusuyla birlikte ele alındığında ortaya ciddi bir çelişki çıkarmaktadır. Muhtarların yönetişim, katılım, yerel demokrasi gibi konularda bilgi düzeylerinin artırılmasının söz konusu çelişkiyi ortadan kaldıracağı değerlendirilmektedir.

Bu çalışmanın bir sonraki aşamasında erkek muhtarlarla aynı amaçları taşıyan bir araştırmanın yapılması planlanmaktadır. Bu sayede kadın ve erkek muhtarların mesleki roller, katılımcı liderlik tutum ve davranışlarını karşılaştırmalı olarak değerlendirmek mümkün olacaktır. Bu çalışmanın ortaya çıkardığı önemli bir sonuç; muhtarların profesyonel liderlik ve mesleki süreçler bağlamında kurumsal eğitimler almaları gerektiğidir. Diğer taraftan muhtarların özellikle muhtarlık kurumu, katılım ve kendilerine verilen yetkiler çerçevesinde belirtmiş oldukları şikâyet ve talepler, ilgili mevzuatta düzenlemelerin yapılması gerektiğini ortaya koymuştur. 
Hakem Değerlendirmesi: Dış bağımsız.

Çıkar Çatışması: Yazarlar çıkar çatışması bildirmemiştir.

Finansal Destek: Yazarlar bu çalışma için finansal destek almadığını beyan etmiştir.

Yazar Katkısı: Çalışma Konsepti/Tasarımı: xx.; Veri Toplama: xx.; Veri Analizi /Yorumlama: xx.; Yazı Taslağı: xx.; İçeriğin Eleştirel İncelemesi: xx.; Son Onay ve Sorumluluk: xx.

Peer-review: Externally peer-reviewed.

Conflict of Interest: The authors have no conflict of interest to declare.

Grant Support: The authors declared that this study has received no financial support.

Author Contributions: Conception/Design of study: xx.; Data Acquisition: xxx.; Data Analysis/Interpretation: xx.; Drafting

Manuscript: xx.; Critical Revision of Manuscript: xx.; Final Approval and Accountability: xx

\section{Kaynakça/References}

Akman, Ç. (2018). Mahalle yönetimi ile ilgili yeni bir yasal düzenleme gerekli mi?: Isparta ili özelinde bir araştırma. Akademik Araştırmalar ve Çalışmalar Dergisi, 10(19), 516-534.

Alada, A. B. (2008). Kentsel yönetime katılımda mahalle. Yerel Yönetimlere Katılım, 64, 66-70.

Arıkboğa, E. (1999). Yerel yönetim açısından mahalle muhtarlığına bir bakış. Çağdaş Yerel Yönetimler Dergisi, 8(3), 103-125.

Ataseven, A., Akış, Ç. E., \& Keyman, F. (2018). Türkiye'de sosyal uyum. İstanbul Politikalar Merkezi, http://ingev.org/raporlar/SosyalUyumRaporu.pdf (Erişim tarihi: 09.07.2020).

Aycan, Z. (2006). Paternalism. In. K. Uichol, Y., Kuo-Shu, H., Kwang-Kuo (Eds) Indigenous and cultural psychology (pp. 445-466). Boston: Springer.

Aycan, Z. (2015). Paternalistic leadership. In Sir C. L Cooper (Ed.) Wiley encyclopedia of management,

http://zeynepaycan.net/doc/paternalistic-leadership-wiley-encylopedia-ofmanagement-2014.pdf Erişim tarihi 05.07.2020).

Aycan, Z., \& Fikret-Pasa, S. (2003). Career choices, job selection criteria, and leadership preferences in a transitional nation: The case of Turkey. Journal of Career Development, 30(2), 129-144.

Baltacı, A. (2018). Nitel araştırmalarda örnekleme yöntemleri ve örnek hacmi sorunsalı üzerine kavramsal bir inceleme. Bitlis Eren Üniversitesi Sosyal Bilimler Dergisi, 7(1), 231-274.

Barnard, I. C. (1938). The functions of the executive. Cambridge, MA: Harvard University Press.

Bulut, Y. (2001). Mahalle muhtarlığı üzerine bir araştırma. Çağdaş Yerel Yönetimler, 10(3), 31-51. 
Bulut, Y. \& Akın, S. (2019). Katılımcı demokrasi açısından mahalle yönetiminin önemi. İçinde Y. Çakırer Özservet ve H. Küçük (Ed.), Mahalle odaklı katılım (s.45-54). Ankara: Astana Yayınları.

Cengiz, A. A. \& Özdemir, A. (2020). Kadın yöneticilere yönelik tutumların oluşumunda çelişik duygulu cinsiyetçilik ve narsisizmin etkisi. Çalışma ve Toplum, 67(4), 21232144.

Creswell, W. J. (2016). Nitel araştırma yöntemleri: Beş yaklaşıma göre nitel araştırma ve araştırma deseni. (M. Bütün ve S. B. Demir Çev.). Ankara: Siyasal Kitabevi.

Çam, E. (2011). Siyaset bilimine giriş. İstanbul: Der Yayınları.

Çadırcı, M. (1993). Türkiye'de muhtarlık kurumunun tarihi gelişimi. Çağdaş Yerel Yönetimler, 2(3), 3-11.

Çukurçayır, M.A. (2012). Siyasal katılma ve yerel demokrasi. Konya: Çizgi Yayınevi.

Eroğul, C. (1999). Devlet yönetimine katılma hakkı. Ankara: İmge Yayınevi.

Ertan, G., Aytaç. S.E., \& Çarkoğlu, A. (2019). Türkiye’de siyasi kurumlara güven: Kültürel ve kurumsal açıklamalar ile "kazanan takım" etkisinin rolü. Hacettepe Üniversitesi İktisadi ve İdari Bilimler Fakültesi Dergisi, 37(1), 65-88.

Eryılmaz, B. (2016). Kamu yönetimi. Kocaeli: Umuttepe Yayınevi.

Eryılmaz, B. (2017). Tanzimat ve yönetimde modernleşme. İstanbul: İşaret Yayınevi.

Esmer, Y. (1999). Devrim, evrim, statüko: Türkiye'de sosyal, siyasal, ekonomik değerler. https://www.tesev.org.tr/tr/research/devrim-evrim-statuko-turkiyede-sosyal-siyasalekonomik-degerler/ (10.07.2020).

Feather, N. T., \& Boeckmann, R. J. (2007). Beliefs about gender discrimination in the workplace in the context of affirmative action: Effects of gender and ambivalent attitudes in an Australian sample. Sex Roles, 57(1-2), 31- 42.

Fine, C. (2011). Toplumsal cinsiyet yanılsaması. (K. Tanrıyar Çev.). İstanbul:Sel Yayıncılık.

Glesne, C. (2016). Becoming qualitative researchers: An introduction. New Jersey: Pearson.

Grijalva, E., Newman, D. A., Tay, L., Donnellan, M. B., Harms, P. D., Robins, R. W., \& Yan, T. (2015). Gender differences in narcissism: A meta-analytic review. Psychological Bulletin, 141(2), 261-310.

Gül, İ. (2019). Değişen kent ve mahalle yönetimi ve katılım. İçinde Y. Çakırer Özservet ve H. Küçük (Ed.), Mahalle odaklı katılım (s.19-44). Ankara: Astana Yayınları.

Harman, W. W. (1981). Two contrasting concepts of participatory leadership. Theory Into Practice, 20(4), 225-228.

Hearn, J. (2004). From hegemonic masculinity to the hegemony of men. Feminist Theory, $5(1), 49-72$.

Hogwood, B.W., \& Gunn, L. A. (1984). Policy analysis for the real world. Oxford: Oxford University Press. 
House, R. J. (1996). Path-goal theory of leadership: Lessons, legacy, and a reformulated theory. The Leadership Quarterly, 7(3), 323-352.

Joseph, T. (2016). Developing the leader-follower relationship: Perceptions of leaders and followers. Journal of Leadership, Accountability and Ethics, 13(1), 132-144.

Kavruk, H. (2018). Mahalle yerleşimi ve yönetimi. Ankara: Nobel Yayınları.

Maxwell, J. A. (2018). Collecting qualitative data: A realist approach. In U. Flick (Ed.) The handbook of qualitative data collection (pp.19-33), London, England: Sage.

Miles, M. B., \& Huberman, A. M. (2016). Genişletilmiş bir kaynak kitap: Nitel veri analizi. (S. Akbaba Altun ve A. Ersoy Çev.). Ankara: Pegem Akademi.

Lüchmann, L.H.H. (2017). Participatory budgeting and democratic innovation: Some analytical variables. In A. A. Paulin, L. G. Anthopoulos, C. G. Reddick (Eds.). Beyond bureaucracy. (pp.63-79). Switzerland: Springer Nature.

Orhan, G., Palaz, S., \& Altan, E. (2018). Yerel siyasete kadınların aktif katılımının koşulları: Kadın muhtarlar akademisi katılımcıları çalışması. Bandırma Onyedi Eylül Üniversitesi Sosyal Bilimler Araştırmaları Dergisi, 1(1), 16-39.

Öktem, M. K. (2019). Değişen kent, mahalle yönetimi ve katılım: Şeffaf muhtarlık. İçinde Y. Çakırer Özservet ve H. Küçük (Ed.), Mahalle odaklı katılım (s.67-86). Ankara: Astana Yayınları.

Özservet Çakırer, Y. (2019). Neden mahalle odaklı katılım?. İçinde Y. Çakırer Özservet ve H. Küçük (Ed.), Mahalle odaklı katılım (s.1-18). Ankara: Astana Yayınları.

Patton, M.Q. (2018). Qualitative research \& evaluation methods (4th ed). Thousand Oaks, CA: Sage.

Rogiest, S., Segers, J., \& van Witteloostuijn, A. (2018). Matchmaking in organizational change: Does every employee value participatory leadership? An empirical study. Scandinavian Journal of Management, 34(1), 1-8.

Rudman, L. A., Moss-Racusin, C. A., Phelan, J. E., \& Nauts, S. (2012). Status incongruity and backlash effects: Defending the gender hierarchy motivates prejudice against female leaders. Journal of Experimental Social Psychology, 48(1), 165-179.

Sancar, S. (2018). Siyasal kararlara katılımda toplumsal cinsiyet eşitliği - Haritalama ve izleme çalışması. http://www.ceidizleme.org/medya/dosya/94.pdf, (Erişim tarihi: 10.07.2020).

Sargut, A. (2007). Kültürler arası farklılaşma ve yönetim. Ankara: İmge Kitabevi.

Somech, A. (2003). Relationships of participative leadership with relational demography variables: a multi-level perspective. Journal of Organizational Behavior, 24(8), 1003 1018.

Spence, J. T., \& Helmreich, R. L. (1978). Masculinity and femininity: Their psychological dimensions, correlates, and antecedents. Austin: University of Texas Press.

Strauss, A., \& Corbin, J. (1990). Basics of qualitative research. CA : Sage Publications. 
Rosette, A. S., \& Tost, L. P. (2010). Agentic women and communal leadership: How role prescriptions confer advantage to top women leaders. Journal of Applied Psychology, 95(2), 221-235.

Yıldırım, A., \& Şimşek, H. (2011). Sosyal bilimlerde nitel araştırma yöntemleri. Ankara: Seçkin Yayıncılık.

Yin, R.K. (2015). Qualitative research from start to finish. New York: Guilford Publications.

Yüce Tar, Y. (2016). "Partisiz siyaset: Muhtarlık": Kadınların siyaseti için bir imkân mı? Samsun ili kadın muhtarları ve kadın muhtar adayları. Journal of International Social Research, 9(42), 1173-1184.

İnternet Kaynakları

Birleşmiş Milletler Kalkınma Programı,

http://hdr.undp.org/en/gsni (Erişim tarihi: 20.05.2020).

Dünya Ekonomik Forumu, Global Gender Report (2020) http://www3.weforum.org/ docs/WEF_GGGR_2020.pdf (Erişim Tarihi: 16.07.2020).

TDK Sözlük,

https://sozluk.gov.tr/ (Erişim tarihi: 12. 03. 2020).

29507 sayılı Genelge, 19 Ekim 2015 “Muhtarlar Günü” konulu Genelge., https://www. resmigazete.gov.tr/eskiler/2015/10/20151019M1.pdf (Erişim Tarihi: 09.05.2020).

5393 sayılı Belediye Kanunu,

https://www.mevzuat.gov.tr/MevzuatMetin/1.5.5393.pdf

URL 1: Muhtarlar Konfederasyonu,

http://www.muhtarlarkonfederasyonu.org/bizden-haberler/turkiye-genelinde-kadinmuhtar-sayisi.html (Erişim Tarihi: 16.04.2020). 
